\title{
Analyzing German consumers' willingness to pay for green electricity tariff attributes: a discrete choice experiment
}

\author{
M. Danne* ${ }^{*}$, S. Meier-Sauthoff and O. Musshoff
}

\begin{abstract}
Background: In order to achieve an environmentally friendly and sustainable energy supply, it is necessary that this goal is supported by society. In different countries worldwide it has been shown that one way consumers want to support the energy transition is by switching to green electricity. However, few people make the leap from their intention to a buying decision. This study explores parameters that influence whether German consumers would hypothetically decide to switch to a green electricity tariff.
\end{abstract}

Methods: A quota-representative online survey including a discrete choice experiment with 371 German private households was conducted in 2016. For the econometric analysis, a generalized multinomial logit model in willingness-to-pay space was employed, enabling the estimation of WTP values to be as realistic as possible.

Results: The results show that consumers' decision whether or not to make the switch to green energy is mainly influenced by the source of green energy, whether a person can outsource the switching process, and a person's attitude towards the renewable energy sources levy that currently exist in Germany.

Conclusions: The findings indicate that politics should focus on supporting wind and solar energy as German consumers prefer these sources over biogas. As the results suggest, the EEG levy is a reason why consumers have lower WTP for switching to a green tariff. Therefore, a switching bonus with a specifically "framed" bonus in the amount of the current EEG levy could be a promising strategy for the increase of green energy tariff acceptance. Furthermore, attention should be given to psychological and behavioral aspects, as the results indicate that these factors influence the consumer's choice for a green electricity tariff.

Keywords: Energy transition, Green energy, Tariff switch, Discrete choice experiment, Generalized multinomial logit model, WTP space

JEL Classification: C23, C25, Q440, Q50

\section{Background}

\section{Introduction}

It is commonly agreed that the climate is changing due to anthropogenic greenhouse gas emissions. Thus, over the last three decades, the goal of bringing a halt to climate

*Correspondence: michael.danne@agr.uni-goettingen.de Department of Agricultural Economics and Rural Development, Georg-August-Universität Göttingen, Platz der Göttinger Sieben 5 , 37073 Göttingen, Germany change emerged. Increasing the share of renewables in energy consumption is a key component of many countries' strategies to achieving climate protection [1-3]. The European Union (EU), for example, aspires to take a leading role and has set ambitious targets in international climate protection [4-6], such as that by 2030 , at least $27 \%$ of its energy should come from renewables [7]. Germany is used as an example in this study, as it is the greatest original author(s) and the source, provide a link to the Creative Commons licence, and indicate if changes were made. The images or other third party material in this article are included in the article's Creative Commons licence, unless indicated otherwise in a credit line to the material. If material is not included in the article's Creative Commons licence and your intended use is not permitted by statutory regulation or exceeds the permitted use, you will need to obtain permission directly from the copyright holder. To view a copy of this licence, visit http://creativecommons.org/licenses/by/4.0/. The Creative Commons Public Domain Dedication waiver (http://creativeco mmons.org/publicdomain/zero/1.0/) applies to the data made available in this article, unless otherwise stated in a credit line to the data. 
greenhouse gas emitter in Europe and is also a country with even more ambitious climate protection goals than other EU countries $[8,9]$. As a member of the EU, the German government laid the foundation for its energy transition process with the Renewable Energy Sources Act (EEG) in 2000 [10]. By 2015, renewable energy sources (RES) already accounted for more than $30 \%$ of the gross electricity consumption in Germany [11]. However, the amendment of the law in 2014 aims to continuously and cost-efficiently increase the share of electricity generated from RES to at least $40 \%$ by 2025 [12].

In addition to political interests that are involved in the promotion of renewable energies, there is also an increasing demand among consumers. Numerous studies show that consumers have an additional willingness to pay (WTP) for electricity from RES [13-21] and that RES should be supported [22]. A meta-analysis found that German consumers have one of the highest WTPs for green electricity compared to consumers of other countries [21].

However, although consumers claim to have a willingness to support the development of renewable energies by purchasing green electricity, the number of actual adoptions of green energy tariffs differs greatly from the intended willingness to change [23, 24]. Thus, it can be assumed that there are obstacles that hinder consumers in the transition to a green electricity tariff, such as high transaction costs, insufficient financial incentives (e.g., no switching bonus payments), and a lack of information on the potential provider or tariff [16, 25-27].

Against this background, the research challenge of this paper is to give new insights into consumers' willingness to switch to green electricity tariffs in order to get a better understanding of the gap between a supportive consumer intention to buy green energy and a low actual tariff adoption rate ${ }^{1}$. It is therefore important to analyze consumers' preferences for green electricity products in order to draw conclusions about their future development potential. Among other studies, Kaenzig et al. [16] published a relevant study on this topic, who used a quota-representative dataset from 2009 to investigate whether German consumers have a WTP for an upgrade from the default electricity mix to a more environmentally friendly electricity mix. To address their research question, they employed a stated preferences survey including a discrete choice experiment (DCE). Borchers et al. [28] analyzed preferences of US consumers for different sources of green energy. They found that solar

\footnotetext{
${ }^{1}$ A preliminary version of the paper, which is available for discussion is published as working paper 1707 of the Department for Agriculture and Rural Development, University of Göttingen
}

energy is preferred over wind and energy from biogas. Yang et al. [29] found that Danish consumers prefer a high percentage of a renewable energy mix at an accessible price level and that they tend to trade with their current energy supplier. They analyzed consumer preferences for wind and hydro energy and an energy mix while solar energy and biogas where not considered. However, it can be observed that the strong expansion of some RES, such as increasing biogas production and installation of wind power plants, has resulted in some negative response, especially from consumers [30-33]. It is therefore of interest for the present study to measure consumer preferences for several single RES, as it can be assumed that these are currently more likely to be valued by consumers than a mix of different (renewable) energy sources, as was investigated by Burkhalter et al. [34], Groesche and Schroeder [35], Kaenzig et al. [16] and Yang et al. [27]. To the best of our knowledge, this study is the first that uses an experimental design that is based on existing comparison portals. This is advantageous since consumers use online comparison portals as their main information resource to gain information regarding different electricity tariffs [36]. To be more precise, the attributes in the experiment and the option offered in comparison portals to outsource the tariff change were chosen based on the model of existing comparison portals. An exception to this approach is the attribute energy source. As described above, this study focusses on the analysis of single RES. However, existing tariffs usually do not distinguish between individual energy sources but offer a mix of them. It follows that the manuscript adds to the existing literature in that it incorporates an experimental design that is very close to existing comparison portals and also analyzes preference for individual RES that have not been studied before.

In this research, a DCE was applied, which allows conclusions to be drawn about future behavior from the results of hypothetical scenarios [37]. In designing the analysis, a referral is made to Fiebig et al. [38], who developed an advanced framework, the so-called generalized multinomial logit (GMNL) model, which considers preference and scale heterogeneity. The latter is particularly relevant, as each consumer interprets and responds to decision situations differently in such choice experiments. Thus, another novelty of this paper is that the GMNL model was transferred to the field of preference measurement in the green energy sector. In order to derive WTP values for the attributes of the DCE that are as realistic as possible, the model was specified in WTP space [39]. Additionally, a further important characteristic of the study is that correlations between the random WTP coefficients of the tariff attributes were allowed. These have often not been regarded in previous WTP 
space studies (with the known exceptions of Balogh et al. [40]; Balcombe et al. [41, 42]. By taking these correlations into account, estimations of consumer preferences for switching to a green electricity tariff are potentially more realistic.

The gap between the WTP for green electricity tariffs and actual adoption poses a problem for both political actors and electricity marketers. However, to enable the best possible energy transition, active participation of consumers in purchasing green electricity is indispensable in the long term. Therefore, this study provides insights for policy-makers and electricity marketers that help to understand what motivates (discourages) consumers to switch to green electricity tariffs.

\section{Theoretical background and development of hypotheses}

To increase the willingness to switch to green electricity and thus to make a long-term contribution to the energy transition, it is necessary to be aware of the drivers and obstacles that are decisive for consumers in choosing such a tariff. In the following, influential factors in the decision-making process of private electricity consumers are considered and hypotheses are developed.

\section{Different preferences regarding various RES}

The source of renewable electricity can influence the consumer's preference when choosing a green electricity tariff. In this context, different studies indicate that most consumers are generally willing to pay extra for green electricity, but the amount of this additional cost varies for different RES [16, 20, 28, 43-46]. Ek [44] found that Swedish households generally favor the production of wind energy. A study by Borchers et al. [28] revealed that, from the US consumer perspective, the benefits of solar power exceed the benefits of wind energy, followed biomass and biogas energy, which were valued similarly and in third place after solar and wind energy. Cicia et al. [43] found a group of Italian respondents who prefer wind and solar energy, but reject energy from biomass. Similarly, Gracia et al. [45] revealed a WTP for solar and regionally produced energy by Spanish consumers, whereas the proposition of wind energy and energy from biomass leads to a request for discount. Burkhalter et al. [34] showed for the German electricity market that an RES electricity mix is more preferred by the consumer than electricity from only one RES. In a more recent study, Kaenzig et al. [16], however, found that the German consumer has a preference order, in which pure wind energy is valued above a green energy mix, which in turn is valued above a mix of renewable energies, coal and nuclear energy. Kosenius and Ollikainen [46] showed for the Finnish case, that energy from plants, which can also be used as food, is the least frequently chosen energy option compared to energy production from wood, wind or water. In a meta-study of the recent literature, Ma et al. [20] described that consumers have a higher WTP for solar and wind energy than for energy from biomass.

The literature reveals that energy from biomass is a component of the green electricity portfolio which is often negatively viewed by consumers $[43,45,46]$. In the German context, energy from biogas in particular is often criticized [16,30], but there is no study that investigates whether consumer rejection of biogas can lead to the decision not to switch to green electricity. Thus, the following hypothesis was derived.

H1 The consumer prefers electricity from solar and wind energy over electricity from biogas.

\section{Influence of where the participant lives}

As far as the effect of consumer socio-demographics on the WTP for green electricity has been considered, the influence of the region and the town size in which the consumer lives has so far been neglected in German studies. However, it can be assumed that both characteristics have an influence on the WTP, since large price differences for green electricity tariffs within the country can be observed $[47,48]$. Furthermore, the town size could stand as a proxy for the degree to which consumers have been exposed to renewable energy, as it is conceivable that consumers in rural areas are more effected, e.g., by the strong expansion of biogas production or the increasing installation of wind power plants [31-33]. However, findings of Liebe et al. [49] and Meyerhoff [50] showed in the context of wind power generation that respondents who already had turbines in their vicinity were more likely to accept new ones than those who have not yet been affected by wind power generation. Hence, the hypotheses were formulated as follows:

$H 2 a$ The participant's WTP for a green electricity tariff is dependent on the region where they live.

$H 2 b$ The participant's WTP for a green electricity tariff is dependent on the town size in which they live.

\section{Influence of a person's attitude towards the EEG levy}

The German Renewable Energy Sources Act guarantees green electricity producers a priority feed-in of their electricity by transmission system operators for a period of 20 years [12]. In accordance with Klaassen 
et al. [51], it is useful to shift the costs of generating and providing electricity from RES to all consumers in order to ensure the development of climate-protecting innovations and the profitability of the electricityproducing industry in the future. In the case of Germany, transmission system operators carry the costs of marketing green electricity to the customers with the so-called EEG levy [52]. In terms of figures, this means that a typical German household with an average annual electricity consumption of 3500 kilowatt hours (kWh) paid about $€ 84$ per month for electricity in 2016, of which the EEG levy accounts for $22 \%$, or $€ 18$ [53]. If consumers have a corresponding WTP, the apportionment model appears appropriate. However, a representative survey conducted by the Renewable Energies Agency (AEE) revealed that $31 \%$ of the participating consumers perceive the EEG levy to be too high [54]. It is conceivable that at least some consumers have this opinion because they generally think that the EEG levy is an unjust instrument to push the expansion of renewable energies. This may lead to consumer backlash and low switching rates [55]. Therefore, the following hypothesis was derived:

H3 The willingness to switch to a green electricity tariff depends on the acceptance of the EEG levy.

\section{Environmental awareness and personal lifestyle}

Numerous studies have confirmed that a relationship exists between environmental awareness of consumers and their preference for the purchase of green electricity [14, 44, 46]. Clark et al. [56] as well as Wiser [57] pointed out that individuals with a greater awareness of their own responsibility in society, knowledge about environmental issues, and a willingness to do something for the environment are more likely to have an interest in electricity from RES. If people acknowledge that climate change exists and that they can contribute to its mitigation through a more environmentally conscious way of life, they often show an increased preference for green electricity [58]. MacPherson and Lange [59] revealed that people with a high income, Green Party supporters, and people with a very environmentally conscious behavior in their everyday life have more often switched to green electricity tariffs in the past. Kotchen and Moore [60] also noted that specific personal characteristics, such as environmental awareness, have an influence on the adoption of a green electricity tariff. Based on these relationships found by previous studies, the following hypothesis was formulated.
H4 An environmentally conscious way of life leads to a higher WTP for green electricity.

\section{Influence of the participant's desire to avoid transaction costs}

Electricity is a low-involvement product, on which the consumer does not want to spend too much time [61]. This is one way to explain why about one-third of the German population still obtains their electricity via basic tariffs, which are the most expensive alternative to receive electricity [62]. 40\% of Germans are dissatisfied with the prices of their electricity tariffs [36], yet only $6.4 \%$ of private households actively switched their electricity suppliers in 2015 [64]. In this context, comparison portals on the internet serve as the main information source for more than half of the households [36]. The advantage of these portals is that they provide the opportunity to gain comprehensive information in a short time. However, by proceeding in this way, the consumer bears the risk of not being able to find the best provider or tariff for their purposes, since the available information overload could confuse them and therefore lead to a status quo keeping behavior. The possibility to outsource the whole switching procedure could therefore increase switching rates. Therefore, the following hypothesis was derived:

H5 The number of tariff switches would increase if consumers could outsource the switching process to someone else.

\section{Methods}

\section{The stated preferences approach}

Preference analysis differentiates between revealed and stated preferences. The former aims to observe real market behavior of individuals. Through the verifiable purchase of a product, "real" preferences become visible [63]. With this approach, however, it is not possible to display preferences for hypothetical scenarios and services [63, 64]. Furthermore, in order to examine the preferences of German households for switching to green electricity tariffs and their WTP for certain tariff attributes, utilization of an experimental design within the stated preferences approach is advisable. By doing so in the present study, it avoided the problem of not being able to get a sufficiently detailed dataset of attributes that influence whether a person switches to green electricity [16]. Therefore, the stated preference approach is the method of choice as it allows for drawing conclusions regarding previously un-articulated preferences [63]. According to Louviere et al. [63], this 
Table 1 Attributes and levels of the DCE for an expected average electricity consumption of $3500 \mathrm{kWh}$ year ${ }^{-1}$

\begin{tabular}{|c|c|c|}
\hline Attributes & Levels & Units \\
\hline Green energy source & $\begin{array}{l}\text { Solar, biogas, wind, renewable energy-mix [45\% wind, 25\% biomass (15\% } \\
\text { biogas), 20\% solar, 10\% hydro power] }\end{array}$ & - \\
\hline Share of green energy & $\begin{array}{l}40 ; 60 ; 80 ; 100 \\
1400 ; 2100 ; 2800 ; 3500\end{array}$ & $\begin{array}{l}\% \text { of the new tariff } \\
\mathrm{kWh}_{\text {year }}{ }^{-1}\end{array}$ \\
\hline Switching bonus ${ }^{\mathrm{a}}$ & $30 ; 60 ; 90 ; 120$ & Euro $(€)$ \\
\hline Price guarantee & $0 ; 6 ; 12$ & Months \\
\hline Tariff price (incl. switching bonus and fees) ${ }^{b}$ & $\begin{array}{l}70 ; 75 ; 80 ; 85 \\
770 ; 825 ; 880 ; 935 \\
22.0 ; 23.5 ; 25.1 ; 26.7\end{array}$ & $\begin{array}{l}\text { Euro month } \\
\text { Euro year }^{-1} \\
\text { Ct kWh }\end{array}$ \\
\hline
\end{tabular}

Source: author's elaboration

${ }^{a}$ The switching bonus refers to a contract term of 12 months. It is a one-time payment that is paid as a discount on the annual tariff price

${ }^{\mathrm{b}}$ The tariff price refers to a contract term of 12 months. Bonus payments are already included in the annual tariff price

approach recognizes preferences as internalized settings of an individual which can be revealed by means of a survey.

Since sufficient empirical data for an econometric analysis of consumers who are about to switch their tariffs were not available, a discrete choice experiment (DCE) was used, in which an attribute-based measure of respondents' preferences was possible through a scenario of hypothetical decision-making situations [37]. This approach has several advantages over a WTP analysis which directly asks participants for WTP values. Firstly, the decision situation for or against a new tariff is closer to reality, since a DCE enables researchers to confront the participants with so-called "choice sets" containing different alternatives that they can choose from [16]. This organizational setting can be understood as a replication of real-life conditions, in which electricity customers are confronted with a broad variety of different tariffs. Each given alternative in this type of experiment consists of pre-defined attributes and their associated levels. These attributes and their levels are then systematically varied to determine the respective influence on the selection decision $[16,63]$. Secondly, the closed design in the choice sets is cognitively less demanding than the open questions, thereby eliminating the risk of "wild guesses". Finally, compared to an open measurement, employing a DCE bears a lower risk of strategic responses, therefore the expressed WTP is more accurate [65].

\section{The discrete choice experiment-attributes and levels}

In the DCE, the participants were confronted in several decision situations with the following hypothetical scenario: "Please imagine that you can switch your electricity tariff today. Your new electricity provider offers you

\footnotetext{
${ }^{2}$ In order to avoid that consumer's think that they have to consume $3500 \mathrm{~kW} / \mathrm{h}$ after a tariff change, this addition was included in the description of the experiment. The $3500 \mathrm{~kW} / \mathrm{h}$ are part of the hypothetical scenario on which basis consumers should make their decision in the DCE.
}

two different tariffs, which both have a contract term of 12 months. The electricity consumption is based on the German average household and amounts in the following tariffs to 3500 kilowatt hours per year. However, this is not the quantity that needs to be taken. ${ }^{2}$ If you opt for one of the two tariffs, your new provider will arrange the termination of the contract with your current supplier, and the switch will be completed. [...] In order to make the choice easier, please imagine that the assumed consumption of 3500 kilowatt hours will later be adjusted to the annual electricity consumption you stated in the beginning". The offered green electricity tariffs varied in the following five attributes: "energy source", "share of green energy", "switching bonus", "price guarantee", and "tariff price". The attributes were selected based on tariff offers of the most popular online switching portals verivox.de and check24.de [66] to enable a realistic experimental design. ${ }^{3}$ Furthermore, the results of a literature review, the analysis of current tariff data, and the findings of a pretest all contributed to the design of the contract alternatives as they are shown in Table 1 . In the pretest, where consumers respondents were selected by the professional online-sampling company respondi, the relevance of different attributes was evaluated by 30 consumers. The DCE in the pretest had "notice period" as additional attribute. However, consumers did not evaluate this attribute as relevant for their decision to switch a tariff. This became obvious by a non-statistically significant coefficient for this attribute as well as by directly

\footnotetext{
${ }^{3}$ So far, there is no contract that has only bioenergy as an electricity source. However, since biogas is evaluated as a rather negative energy source compared to the other RE sources it is valuable to analyze biogas as single source $[28,30,32]$.
} 
Table 2 Example of one of the choice sets in the DCE

\begin{tabular}{|c|c|c|c|}
\hline & Tariff A & Tariff B & No switch \\
\hline Green energy source & Solar & Wind & \\
\hline Share of green energy ${ }^{a}$ & $80 \%=2800 \mathrm{kWh}$ & $60 \%=2,100 \mathrm{kWh}$ & \\
\hline Switching bonus & $€ 30$ & $€ 90$ & \\
\hline Price guarantee & 6 months & 6 months & \\
\hline Tariff price for 3.500 kWh (incl. switching bonus and fees) ${ }^{b}$ & $\begin{array}{l}75 € / \text { month } \\
825 € / \text { year } \\
23.5 \text { Cent/kWh }\end{array}$ & $\begin{array}{l}85 € / \text { month } \\
935 € / \text { year } \\
26.7 \text { Cent/kWh }\end{array}$ & \\
\hline Which alternative do you choose? & $\mathbf{O}$ & $\mathbf{0}$ & $\mathbf{0}$ \\
\hline
\end{tabular}

Source: author's elaboration

${ }^{a}$ The absolute share of green energy in the tariff is related to an expected average electricity consumption of $3500 \mathrm{kWh}^{2} \mathrm{year}^{1}$

${ }^{b}$ Advance payments for electricity and gas are calculated for either 12 months or 11 months. Because in Germany the 11-month model is the more common one, it is used in the DCE. This information was given to consumers in the attribute description

asking consumers for the most relevant attributes for a tariff switch. Testing the suitability of the attributes in a pilot study aims to reduce task complexity. Task complexity increases as the number of attributes, levels or choice sets increases. This influences, on the one hand, the practicability of the experiment, since high complexity will result in increasing effort for participants. On the other hand, complexity can result in increasing unobserved variability [67]. Therefore, it is recommendable in choice design to use only as many attributes and levels as is necessary. The attribute-levels were related to an expected annual electricity consumption of $3500 \mathrm{kWh}$, the German average household consumption [62] and a contract term of 12 months as this is the standard contract term. However, consumers were also told that they do not have to consume the $3500 \mathrm{kWh}$ when selecting a tariff, but that the annual bill will be adjusted to their individual consumption based on the respective price per kilowatt hour.

Each decision situation (choice set) provided two different and mutually exclusive tariff alternatives. The tariffs were neutrally referred to as "Tariff A" and "Tariff B", so as not to indicate any differences. Furthermore, the choice sets contained a status quo alternative ("no switch"), since consumers have the opportunity to keep their current tariffs under real-life conditions as well. As consumers have to decide for one of these three alternatives, each choice card will produce one observation.

\section{The experimental design}

The experimental design of the DCE comprised two generic alternatives, four attributes with four levels each and one attribute with three levels (cf. Section "The discrete choice experiment-attributes and levels"), thus resulting in a full-factorial design with $\left[(4 \cdot 4 \cdot 4 \cdot 4 \cdot 3)_{\text {Tariff }}\right.$ A $(4 \cdot 4 \cdot 4 \cdot 4 \cdot 3)_{\text {Tariff }}$ B $\left.=\right] 589,824$ possible decision situations or choice sets. In this design, all possible main and interaction effects were included [68]. However, for the sake of practicability, this design was determined to be too extensive and therefore, the number of choice sets was reduced. To minimize the simultaneous and unavoidable loss of information when reducing the full-factorial design, a so-called "efficient design" was applied. Efficient designs [68-70] require ex ante information regarding the population's utility parameters since these designs aim to minimize the standard errors of the utility parameters for the estimation process. This information for the final experiment was obtained by conducting a pretest with 30 participants. As a result, a D-efficient Bayesian design $[69,71,72]$ was found to be appropriate for our purpose (D-error: 0.051). Thus, the number of choice sets presented to the participants in the final survey was reduced to 12 . As an example, one of the 12 choice sets is depicted in Table 2. A complete list of the choice sets and the experimental setting can be found in Additional file 1: Appendix S1.

\section{Data collection}

For the empirical analysis, primary data were collected from residential electricity customers in Germany. An online survey was designed to investigate consumers' preferences for green electricity tariffs and their switching behavior. The final sample was drawn by quota sampling, taking into consideration the distribution of the participants by monthly net income of the household, persons living in one household, and region (north, east, south, and west Germany) since it was expected these characteristics were appropriate for testing the derived hypotheses. The participants were selected by a professional online-sampling company (respondi) in July and August 2016. In order to be suitable for the survey and the DCE, the participants had to confirm that they are responsible for their household's energy-related decisions. Then, participants who met all the necessary 
criteria were recruited. In the survey, participants were firstly asked to provide their electricity consumption data. Next, the DCE was conducted by presenting the choice sets in a randomized order. Then questions were raised to identify differences in the participants' perceptions of green energy sources and their sensitivity towards environmental and climate change issues. The final part of the survey was dedicated to collecting sociodemographic data. In total, 420 respondents finished the survey. Data from 49 respondents were not suitable for the analysis because of implausible or incomplete answers. ${ }^{4}$ As respondi was responsible for the data collection, it is unclear how many participants cancelled the survey prematurely. A desired number of participants and the fulfillment of certain quotas were defined. It is not known how many participants respondi needed to meet these parameters. Finally, a total of 371 participants submitted surveys that could be used for further analysis. Answering the survey took $22 \mathrm{~min}$ on average.

Excluding the DCE, other data obtained from the survey served as explanatory variables for testing the derived hypotheses. Table 3 gives an overview of which statements from the survey were chosen as additional explanatory variables.

\section{Model selection}

In order to derive WTP values for the attributes of the DCE with the ultimate goal of giving recommendations for policy-makers and the energy sector, an approach that could produce realistic WTP values was needed. In this context, models in preference space are the current standard method for estimating the WTP of individuals.

One of the main assumptions of these models is that the price coefficient is fixed across individuals. This is necessary because otherwise the WTP is derived by calculating the ratio of two randomly distributed terms, namely the ratio of the distribution of the non-monetary attribute and the distribution of the price coefficient. Unfortunately, this procedure often results in unrealistic and invalid distributions for the WTP [72, 73]. However, handling the price coefficient as a fixed value is an unnecessarily restrictive assumption as it does not account for heterogeneity in the price coefficient and furthermore, assumes that the scale parameter and therefore, the variance in the error term are identical for all individuals.

\footnotetext{
${ }^{4}$ Most of them (8\%) were removed because the relation between their indicated electricity consumption and their annual electricity costs were strongly unrealistic. For instance, they indicated to consume 1000-1500 kWh and have to pay $€ 1300-1399$ per year. Others were removed because the time they needed to finish the survey was extremely short so that we had doubts that using this data will result in reliable results.

5 The re-formulation of the model is shown in Additional file 1: Appendix S2.
}

Consequently, this unidentified scale heterogeneity can be erroneously attributed to a variation in the WTP [64].

However, models in WTP space are able to overcome this problem since coefficients of the WTP are directly estimated by re-formulating the model. ${ }^{5}$ In this case, assumptions regarding the distributions of the WTP are made directly rather than on the attribute coefficients. Therefore, in these models, it is possible to differentiate preference from scale heterogeneity, and hence to account for differences in the degree of heterogeneity in the DCE. A stated preference approach was used in the study, so this aspect of the method is particularly relevant, since each consumer interpreted and responded to each decision situation differently. By applying a generalized multinomial logit (GMNL) model in WTP space [38], the results were estimated while taking preference and scale heterogeneity into account.

Studies analyzing DCEs with GMNL models in WTP space can be found in a growing number of fields such as food production [28], environmental sciences [74] and agricultural economics [75, 76]. However, despite the great advantages of this model specification, it had not been used previously for measuring consumer preferences in the field of energy from RES. The general equations underlying the estimation process can be found in Additional file 1: Appendix S2.

\section{Results and discussion \\ Description of the sample}

The sample was drawn by quota sampling, taking the following factors into consideration: participating households' monthly net income, the number of persons living in one household, and region. It was expected that region and town size could affect the decision for or against an offered tariff. Therefore, the German federal states were divided into four regions ${ }^{6}$ based on the cardinal directions. The variable "town size" was divided into five groups, and ranged from "less than 5000 residents" to "more than 500,000 residents" following the classifications of the German Federal Statistical Office (see Additional file 1: Appendix S3).

The participating consumers were aged between 18 and 78 years, with a representative average of 44 years of age [77]. Individuals younger than 18 years of age were not included in the survey, since few people younger than 18 live in their own households and make decisions regarding their electricity tariffs. In the sample, females were

\footnotetext{
${ }^{6}$ The distribution of the federal states to the regions was as follows: north (Bremen, Hamburg, Lower Saxony, Schleswig-Holstein), east (Brandenburg, Mecklenburg-Western Pomerania, Saxony, Saxony-Anhalt, Thuringia, Berlin), west (North-Rhine Westphalia, Saarland), south (Bavaria, Baden-Wuerttemberg, Hesse, Rhineland-Palatinate).
} 


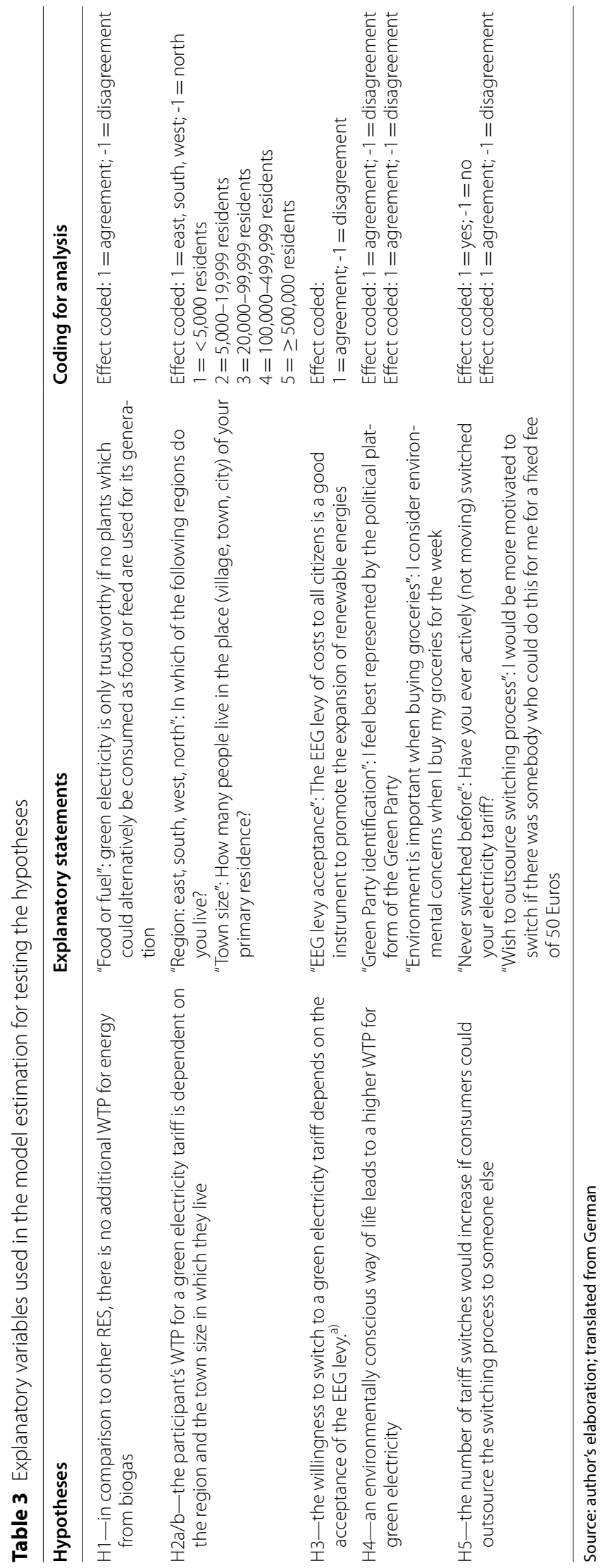


slightly overrepresented compared to the general German population in 2015 (57\% vs. 52\%) [78]. However, since the focus of this investigation was rather on individuals who are responsible for household energy-related decisions, the gender distribution of surveyed decisionmakers may differ from the general German population. A total of $24 \%$ of sampled individuals had obtained the general higher education entrance qualification and another $24 \%$ held a university degree as the highest qualification level.

Considering the electricity consumption data, participants used $2750 \mathrm{kWh}$ per year on average and paid about $€ 750$ for their annual electricity bill. The latter value is considerably lower than the annual average German average annual electricity bill, which amounted to $€ 1008$ in 2016 [53]. This difference may be due to the assumption that an average household has an electricity consumption of $3500 \mathrm{kWh}$ per year, while in our sample, $69 \%$ of the respondents stated that they consume less. 35.3\% receive electricity from green energy, meaning that they have tariff that includes $100 \%$ RES. $^{7}$ Furthermore, only $6.4 \%$ of all German households switched their energy provider in 2015, meaning that few people have benefited from a cost reduction in their electricity bill [62], whereas in our sample, a quarter of the individuals switched their provider or tariff within the past year.

Statements relevant to the hypotheses showed the following response frequencies: half of the sampled individuals stated that green electricity is only trustworthy if no plants which could alternatively be consumed as food or feed are used for its generation. A quarter of the participants agreed that the EEG levy is a good instrument to promote the expansion of renewable energies. However, $63 \%$ agreed that the demand for green energy could be increased through the elimination of the EEG levy for those who decide to receive pure green energy. $12 \%$ of the participants felt well-represented by the political platform of the Green Party, which was slightly more than in the 2017 general election [79]. 52\% of individuals considered environmental concerns when they buy their groceries. Although two thirds of participants had a positive attitude towards green energy, $31 \%$ of the participants had never taken the initiative to switch. About $16 \%$ of the participants would be more motivated to switch if there was somebody who could do this for them for a fixed fee of 50 Euros. Full descriptive statistics are provided in Additional file 1: Appendix S3.

\footnotetext{
${ }^{7}$ In our questionnaire, we have asked whether consumers already have a green energy tariff or not. We assume that participants are aware that offered green energy tariffs in reality only include RES. In future studies this assumption should be validated.
}

\section{General findings of the GMNL model in WTP space}

Table 4 presents a basic model (Model 1) which represents the WTP of the average consumer as well as a model that includes several participant-specific variables as interaction terms with different tariff attributes (Model 2). Both were estimated in WTP space as a specified form of the GMNL model $[35,36]$ by implementing the Stata module of Gu et al. [80] using 1000 Halton draws. These interaction terms account for possible causes of the observed heterogeneity in the valuation of the random parameters "alternative-specific constant (ASC)", "share of green energy", "switching bonus", and "price guarantee" which are characterized by the standard deviations of the random parameter distributions of Model 1. As suggested by Hensher et al. [81], interactions that were not significant were excluded from the estimation process as they could have had an effect on the other coefficients within the model. Therefore, other tested variables, such as the participants' educational level or the size of the household, were not considered in the final model estimation since they lacked significance. In order to prove the explanatory power of the models, the pseudo- $\mathrm{R}^{2}$ was used as a goodness-of-fit measure. The values show that Model 2, with a pseudo- $R^{2}$ of 0.32 , is an improvement of Model 1. According to Hensher et al. [81], a pseudo$R^{2}$ of at least 0.3 represents an appropriate model fit. The underlying STATA-code can be found in Additional file 1: Appendix S4.

The price coefficient was normalized to -1 , and the other coefficients represent the WTP for each variable. The models include a dummy-coded ASC, which was valued at one for choosing one of the tariff alternatives and zero for the status quo alternative "no switch". The significant ASC of Model 1 implies that the average participant is willing to pay 21.6 Euro $\mathrm{kWh}^{-1}$ for an offered green electricity tariff instead of choosing no offered tariff (status quo alternative). This value reflects a general WTP for green electricity as all offered tariffs within the DCE contained green electricity. On average, German consumers paid about 28.8 Euro $\mathrm{kWh}^{-1}$ for their electricity in 2016 [53], indicating that a tariff switch can be strongly motivated by a price reduction. However, this relatively high value arises from the fact that about one-third of the consumers received electricity via basic tariffs, which are the most expensive way to obtain electricity [62]. Considering all available existing pure green energy tariffs in Germany, the average cost for one kilowatt hour was only 22 Euro $\mathrm{kWh}^{-1}$ in 2016 [47]. Therefore, it can be assumed that the estimated WTP of 21.6 Euro $\mathrm{kWh}^{-1}$ for switching to a green electricity tariff reflects a realistic amount.

The attribute "share of green energy" was measured in percentage and described the proportion of green energy sources in the tariff for an annual electricity consumption 
Table 4 Generalized multinomial logit model in willingness-to-pay space

Variables

GMNL-WTP-space I Basic model

Coefficient (mean)

$\begin{array}{ll}21.649^{* * *} & 27.983^{* * *} \\ 0.022^{* * *} & 0.027^{* * *} \\ 0.004^{* *} & -0.002 \\ 0.148^{* * *} & 0.063^{* *} \\ -1[\text { fixed] } & -1[\text { fixed] } \\ & \\ 0.211^{* *} & 0.188^{* *} \\ 0.196^{* *} & 0.178^{* *} \\ 0.059 & 0.067\end{array}$

Random parameters

Alternative-specific constant (ASC) ${ }^{a}$

Share of green energy

Switching bonus

Price guarantee

Tariff price

Non-random parameters ${ }^{b}$

Green energy source: solar

Green energy source: wind

0.059

ASC region: east ${ }^{c}$

ASC $\times$ region: south ${ }^{c}$

ASC $\times$ region: west $^{c}$

ASC $\times$ town size ${ }^{d}$

ASC $\times$ EEG levy acceptance ${ }^{e}$

ASC $\times$ Green Party identification ${ }^{e}$

Share of green energy $\times$ green Party identification ${ }^{e}$

ASC $\times$ food or fuel ${ }^{e}$

ASC $\times$ environment is important when buying groceries ${ }^{e}$

ASC $\times$ never switched before ${ }^{f}$

ASC $\times$ wish to outsource switching process ${ }^{e}$

\begin{tabular}{|c|c|}
\hline & $0.502^{* *}$ \\
\hline & $-1.139^{* * *}$ \\
\hline & $0.671^{* * *}$ \\
\hline & $-0.496^{* * *}$ \\
\hline & $0.555^{* * *}$ \\
\hline & $-1.038^{* * *}$ \\
\hline & $0.010^{* * *}$ \\
\hline & $-0.646^{* * *}$ \\
\hline & $1.130^{* *}$ \\
\hline & $-0.381^{* * *}$ \\
\hline & $1.279^{* * *}$ \\
\hline $5.654^{* * *}$ & $4.999 * * *$ \\
\hline $0.023^{* * *}$ & $0.020 * * *$ \\
\hline $0.010^{* * *}$ & $0.007^{* * *}$ \\
\hline $0.088^{* * *}$ & $0.116^{* * *}$ \\
\hline $1.014^{* * *}$ & $1.137^{* * *}$ \\
\hline $371 / 4,452$ & $371 / 4,452$ \\
\hline 0.309 & 0.322 \\
\hline-2716.756 & $-2,670.03$ \\
\hline 5471.512 & 5408.06 \\
\hline
\end{tabular}

Standard deviations (SD) of parameter distributions

SD ASC

SD Share of green energy

SD Switching bonus

SD Price guarantee

Scale heterogeneity

Tau

Goodness of fit measures

Participants/observations

McFadden pseudo- $R^{2}$

Log-likelihood at convergence

Akaike information criterion
$0.502^{* *}$

GMNL-WTP-space

II Interaction

model

Coefficient (mean)

$-1.139^{* * *}$

$-0.496^{* * *}$

$.555^{* * *}$

$010 * * *$

$0.646^{* * *}$

$-0.381^{* * *}$

$279 * * *$

$999 * * *$

$020 * * *$

$.007^{* * *}$

$116^{* * *}$

$.137^{* * *}$

$71 / 4,452$

$-2,670.03$

Source: author's calculations by means of the STATA-command "gmnl" in STATA 14 using 1000 Halton draws

${ }^{*} p<0.1 ;{ }^{* *} p<0.05 ;{ }^{* * *} p<0.001$; randomized WTP coefficients with significant SD are assumed to be normally distributed and correlated; the price coefficient was

normalized to be log-normal and constrained to -1

a Binary coded variable; reference: status quo alternative "No switch."

b Effect coded; reference: "Energy source: biogas"

"Effect coded; reference: "Region: north"

d The variable "town size" was divided into five groups, and ranged from "less than 5000 residents" to "more than 500,000 residents". For a detailed structuring of the groups see Additional file 1: Appendix S3

e Effect coded; reference: "Participant does not support the queried statement"

${ }^{f}$ Effect coded; reference: "Participant switched the electricity tariff at least once before" 
of $3500 \mathrm{kWh}$. Model 1 shows that on average, the WTP increased by 0.022 Euro $\mathrm{kWh}^{-1}$ if the share of green energy increased by $1 \%$. For instance, the lowest offered green energy share in the tariffs was $40 \%$, resulting in an additional WTP of 0.88 Euro $\mathrm{kWh}^{-1}(0.022 * 40)$, meaning that participants would agree to pay 2.2 Euro $\mathrm{kWh}^{-1}$ $(0.022 * 100)$ more for a pure green energy tariff if they decided to switch their tariff. In terms of the annual electricity bill, this means a sum of $€ 77\left(0.022^{*} 100 * 3500\right)$. The influence of the "switching bonus" was also significant if the participants were willing to opt for a new tariff. Model 1 reveals that for a one Euro increase in the bonus payment, participants would pay 0.004 Euro $\mathrm{kWh}^{-1}$. Thus, in order to receive the maximum offered switching bonus of $€ 120$, the average participant was willing to spend $€ 16.80$ $€(0.004 * 120 * 3500)$ more on the annual electricity bill. The "price guarantee" was given in months and led to a relatively high WTP, as shown in Model 1. If the average participant decided to switch their tariff, they were willing to pay 0.15 Euro $\mathrm{kWh}^{-1}$ for every additional month the guarantee is extended. In other words, regarding an annual electricity consumption of $3500 \mathrm{kWh}$, a 12-month guarantee was valued by the average participant at $€ 63$. The variable "energy source" was effect coded, meaning that "biogas" acted as a reference for the other energy sources. The coefficient for biogas was then calculated as suggested by Hensher et al. [81] using the following equation: $\mathrm{WTP}_{\text {biogas }}=-\left(\mathrm{WTP}_{\text {solar }}+\mathrm{WTP}_{\text {wind }}\right)$. Thus, the coefficient was $-0.407(-0.407=-(0.211+0.196))$, as it can be understood from Model 1. This suggests that participants had a WTP for a tariff including solar or wind energy but not for a tariff with biogas energy. Furthermore, no significant WTP for a renewable electricity mix was found.

\section{Hypotheses testing}

\section{Hypothesis 1 Different preferences regarding RES.}

The results of Model 1 reflecting the average consumer's preferences were used for testing Hypothesis 1 since no preference heterogeneity was determined for the coefficients of the energy sources "solar", "wind", and "RE mix". The green energy source "biogas" acted as a reference for the other energy sources. The results revealed that consumers have a marginally higher WTP for solar energy than wind energy (coefficients: 0.211 vs. 0.196) if "biogas" is understood as the reference. Furthermore, a renewable electricity mix does not motivate participants to pay more for biogas in a potential new tariff, as the coefficient was not significant. If consumers have the choice between the various energy sources presented in this study, neither biogas nor a RE mix are energy sources that facilitate an increased rate when switching the tariff. This is contrary to Burkhalter et al. [34], who reported that a green electricity mix is more appreciated by consumers than green electricity from a single source. However, if consumers have a negative perception of biogas production and more specifically, of RES that can alternatively serve as feed or food [43, 46], it seems plausible that a green electricity mix containing energy of this origin is more likely to be rejected. This assumption was confirmed by the negative coefficient of the interaction term "ASC $\times$ food or fuel" (Model 2: -0.646 ). Without accounting for specific tariff arrangements, it was shown that if a participant does not want to support an energy source that can either serve as food or fuel, their WTP decreases by 0.646 Euro $k W h \neg 1$. Consequently, the results corroborate other scientific studies that also found that if consumers consider switching to green energy tariffs, they have a general WTP for green electricity products, but that this varies over different energy sources [16, 20, 28, 43-46]. In light of these results, H1: the consumer prefers electricity from solar and wind over electricity from biogas can be confirmed.

\section{Hypotheses 2a/b Influence of where the participant} lives.

The northern states of Germany served as the reference for the estimations in Model 2, since consumers pay an average value for green electricity compared to the other regions [47]. The results showed that compared to the north, the south has the significantly lowest WTP for switching to green electricity (ASC $\times$ region: south: -1.139 Euro $\mathrm{kWh}^{-1}$ ), whereas households in the east or west would pay significantly more than households in the north for switching to green electricity (ASC $\times$ region: east: 0.502 Eurocent $\mathrm{kWh}^{-1}$, ASC $\times$ region: west: 0.671 Euro $\mathrm{kWh}^{-1}$ ). One possibility to explain these regional differences is to take the different network charges that consumers have to pay depending on the network operator into account. In general, it can be stated that households in the east pay significantly more for their electricity than households in the west $[47,48,82]$. This results from higher costs for the network expansion in the east, since here lots of renewable energy is produced which needs to be then fed in the grid and distributed. However, the study did not find that households in the east want a discount compared to the reference households in the north. Therefore, another path to explain the findings could be that even if different WTP values for switching to green energy are found in different regions, these values are not different because of the region and the average electricity price in each region. The household size, the income situation, as well as the tariff 
availability depending on where a participant lives, could have influenced the participants' WTP in the observed regions.

The coefficient "ASC $\times$ town size" was significantly negative $(-0.496)$. The coefficient can be interpreted as follows: the bigger the town a person lives in, the lower the WTP for a green electricity tariff switch. In other words, participants who live in very large cities with more than 500,000 residents have five times lower WTP $\left(-2.48\right.$ Euro $\left.\mathrm{kWh}^{-1}\right)$. In terms of the annual electricity bill, this means that these participants want to pay about $€ 86.80$ less $\left(5^{*}(-0.496) * 3500\right)$. This is an interesting finding, as on the one hand, it is conceivable that people who live in rural areas (represented by the smallest town unit) are more impacted by negative effects of renewable energy production, and therefore it could be expected that these participants would have the lowest WTP. On the other hand, and this is what the results suggest, it can be assumed that these participants are probably closer to nature and more involved in renewable energy production, and therefore have the highest WTP. This is in line with findings of Liebe et al. [49] and Meyerhoff [50] who showed in the context of wind power generation that respondents who lived further away from turbines were more likely to be opponent to wind power generation, whereas respondents who already had turbines in their vicinity were more likely to accept new ones. However, since this is probably the first study that considered the influence of where a person lives on whether a person wants to switch to green energy or not, further studies could analyze why consumers in towns want to pay less. Nevertheless, it becomes evident that H2: the participant's WTP for a green electricity tariff is dependent on the region and the town size cannot be rejected.

Hypothesis 3 Influence of a person's attitude towards the EEG levy.

The survey included the question of whether the participants perceived the EEG levy of costs to all citizens as a good instrument to promote the expansion of renewable energies. About $26 \%$ of the sample agreed with this. For those who supported this statement, the WTP increased significantly (by 0.56 Euro kWh-1) if they decide to switch their tariff ("ASC $\times$ EEG levy: likely instrument"). However, the WTP decreased by the same amount for individuals who disagreed with this statement. In terms of the annual electricity bill, this amounts to $€ 19.60$ and shows that participants were (not) willing to pay more. As the EEG levy, in reality, costs consumers $€ 216$ per year at a consumption level of $3500 \mathrm{kWh}$ [51], the findings indicate that the WTP of participants who agreed (disagreed) with the EEG levy was $€ 236$ (€196). Thus, H3: the willingness to switch to a green electricity tariff depends on the acceptance of the EEG levy cannot be rejected, even if the influence of a person's attitude is rather modest in terms of concrete figures. However, to explain why the majority of the participants want to reach a tariff price discount by reducing the amount of the EEG, it may be helpful to know that currently only $42 \%$ of the EEG levy is used to promote the expansion of renewable energies [83]. If participants have knowledge of this, it is conceivable that they consider the EEG levy to be an inappropriate mechanism. This assumption was additionally supported by $63 \%$ of participants, who stated in the survey that the demand for green energy could be increased through the elimination of the EEG levy for those who decide to receive pure green energy. For policy-makers, this could be an interesting approach to motivate consumers to buy pure green energy. Consumers who decide to opt for a pure green energy tariff could be rewarded with a discount in the amount of the EEG levy, whereas all other groups of electricity customers who do not support the energy transition by purchasing green energy might be charged a penalty.

\section{Hypothesis 4 Environmental awareness and personal} lifestyle.

It seems obvious that people with a high awareness regarding environmental and sustainability issues are more likely to be interested in buying green electricity $[54,57,58]$. One way to gain information about consumer awareness is to ask whether participants are Green Party supporters [59]. In this study, the question was raised whether participants feel represented by the political platform of the Green Party. Those who identified with the Green Party showed a significantly reduced WTP for a switch to the offered green energy tariffs ("ASC $\times$ Green Party identification" $=-1.038$ ). This might be due to the fact that from the viewpoint of Green Party supporters, the offered tariffs could have included unfavorable energy sources, such as biogas. Interestingly, it was evident that the same participants had a rising WTP for each percentage increase in the share of green energy in the offered tariff ("share of green energy $\times$ Green Party identification" $=0.010$ ). Therefore, it is conceivable that participants who felt represented by the Green Party considered switching to a green energy tariff only if this tariff consisted of pure green energy sources. If this is true, other tariffs that comprise lower shares of green energy, including the electricity mix currently offered in Germany, might not be a successful way to encourage this consumer group to switch to "greener" energy tariffs.

The influence of awareness of environmental issues on the participants' decision to switch tariffs was also 
shown by the significant coefficient of the interaction term "ASC $\times$ environment is important when buying groceries" $=1.130$. This result indicates that consumers who consider environmental issues in their daily life, e.g., when doing the weekly grocery shopping, have a higher WTP for switching to a green energy tariff. It is also conceivable that consumers who aspire to lead an environmentally friendly lifestyle are more likely to switch their energy tariff to a green energy tariff since this kind of energy contributes to their desired way of life. Consequently, H4: an environmentally consciousness way of life leads to a higher WTP for green electricity cannot be rejected.

Hypothesis 5 Influence of the participant's desire to avoid transaction costs.

There are several reasons why consumers do not switch their electricity tariffs, even if switching results in a financial benefit [25-27]. It was revealed that if a participant had never switched their tariff before, then they had a significantly lower WTP regarding a switch to a green energy tariff ("ASC $\times$ never switched before" $=-0.381$ ). This result confirms that certain obstacles exist for consumers when they switch their tariff. Thus, participants were asked in the survey whether they were more motivated to switch if they could outsource the switching process to someone else. The significant coefficient of the interaction term "ASC $\times$ wish to outsource the switching process" $=1.279$ shows that participants who want to outsource the switching process demonstrate their appreciation of this assistance with an increased WTP. In light of these results, H5: the number of tariff switches would increase if consumers could outsource the switching process to someone else is supported and cannot be rejected. Therefore, offering a "full-service switch" or to work together with switching assistants could be one way to increase green energy adoption rates. In most cases, the termination of the current electricity tariff is already handled by the new provider. However, the consumer must cancel the tariff in some cases, e.g., in the case of moving house. Therefore the results reveal that consumers evaluate this service positively and providers should continue and extend the possibility of a "full-service switch".

\section{Conclusions}

This paper presents the results of a quota-representative discrete choice experiment with 371 German electricity consumers conducted to elicit factors that are important for consumers when deciding whether or not to switch to green electricity. In order to provide policy-makers and marketers with a valuable understanding of consumer behavior with regard to demand for green energy electricity, an estimation approach was chosen that produces WTP values that are as realistic as possible. Therefore, this study allows policy-makers and electricity marketers to gain insights into how specific parameters influence consumers' WTP, which might be worth considering in order to increase adoption rates of green energy electricity in private households. This is particularly important as Germany aims to rely solely on renewable energy sources in the future [84].

Considering the gap between consumers' intentions and consumers' actions, the following implications can be drawn from the results of this tariff switching experiment: in order to make switching to green energy tariffs more attractive for consumers, electricity marketers and policy-makers should focus on support of pure green energy tariffs that solely consist of solar or wind energy. As the findings indicate, German consumers are reluctant to switch to a green energy tariff if the source of green energy is biogas or a mix of different renewable energies containing biogas as a source. This is supported by the result stating that if plants which can also serve as food or livestock feed are used to produce green electricity, the WTP decreases for a green energy tariff. Therefore, the support of solar and wind energy should be a priority for politicians as these energy sources are specifically demanded by the consumer. In addition, marketers could demand higher prices if they can offer such differentiated tariffs.

Although in most cases there is no difference between the switching bonus for green energy and conventional tariffs it is important to consider this attribute in the DCE. A switching bonus is offered in many cases as an incentive, especially on online platforms. To analyze the trade-off of the switching bonus with other relevant factors and to design tariffs that are as realistic as possible, it was necessary to regard this attribute. Nevertheless, the attribute switching bonus has to be validated in future studies.

A further implication is that marketers should replace the "general" switching bonus with a specifically "framed" bonus in the amount of the current EEG levy. As suggested by the results, the EEG levy is a reason why consumers have lower WTP for a switch to a green tariff. Therefore, a "framed bonus" could be a promising way to increase adoption rates of green energy tariffs, especially for those who are critical of the EEG levy. Furthermore, policy-makers could take this point as a suggestion to consider whether a reward and punishment policy could be more promising than the current EEG levy to promote renewable energy expansion.

The study also suggests that attention should be given to psychological and behavioral aspects, as they have a 
great influence on consumers in their decision whether or not to switch to green energy. This is in line with Tabi et al. [58], who also suggested that these aspects should be considered "when it comes to understanding why consumers who evince strong preferences towards electricity produced from renewable energy sources do not act according to their preferences by opting to purchase green power". The study found, for example, that if marketers offered a "full-service switch" or a "subscription for frequent switches", this could be a great opportunity to increase green tariff adoption rates for consumers who try to avoid transaction costs. However, there may also be other factors that play a role when consumers consider outsourcing the switch. Therefore, further research could investigate which authorities consumers consider to be trustworthy enough to carry out the switch for them.

These conclusions are based on the results of a DCE. Although we designed the experiment as realistically as possible and used an analytical approach that enables estimation of actionable WTP values, the level of WTP determined in this study should be interpreted with having in mind that there are various influences that can affect the WTP level. Reasons for the so-called hypothetical bias are described in a meta-analysis by [85]. They found for example that the hypothetical bias is higher for products with a higher search and price comparison effort. In addition, the bias is higher for products that require a higher proportion of the consumers' budget. A further issue is the extent to which the topic and the consumers experience have an impact on the results. This may have also an effect on how the attributes and levels will be interpreted by respondents [86]. From this it can be concluded that our results must be verified with further studies. Furthermore, findings regarding the region and town size suggest more investigation is necessary in order to determine the influence of these characteristics on the consumers' WTP for green energy. Therefore, the population of rural areas and their exposure to RES production should be investigated more in detail. Additionally, as the results relate to a fixed annual electricity consumption of $3500 \mathrm{kWh}$, reflecting the average German household [53], it could be interesting to design a DCE, which relies on the real consumption data of the participating individuals. Such an adjustment could be helpful to reduce the potential hypothetical bias that may lead to overestimation of the WTP in choice experiments [20, 87]. In addition, the hypothetical scenario in the DCE includes eleven advance payments per year. Because in Germany, also 12 advance payments are possible, future research should validate our results by explicitly analyzing potential influences of different advance payments. Furthermore, this study is limited to Germany, so it would be enlightening if further research could apply the experimental design to investigate whether consumers in other countries have similar preferences.

\section{Abbreviations}

AEE: Renewable Energy Agencies; ASC: Alternative-specific constant; DCE: Discrete choice experiment; EEG: Renewable Energy Sources Act; EU: European Union; GMNL: Generalized Multinomial Logit; kWh: Kilowatt hours; RES: Renewable energy sources; SD: Standard deviation; WTP: Willingness to pay.

\section{Supplementary Information}

The online version contains supplementary material available at https://doi. org/10.1186/s13705-021-00291-8.

Additional file 1: Appendix S1. The discrete choice experiment (DCE). Appendix S2. Development of the willingness to pay (WTP) in WTP space. Appendix S3: Table S1. Descriptive statistics of the sample. Appendix S4. STATA code for the estimated generalized multinomial logit model in WTP space.

\section{Acknowledgements}

We thank Mrs. Aoife Neville for checking the language of this paper. We would also like to thank our three anonymous reviewers for their valuable comments and remarks.

\section{Authors' contributions}

MD, SS and OM contributed to the design of the work. MD and SS are responsible for acquisition of data (in Germany), drafting of the work, and management work. MD analyzed the data. All authors read and approved the final manuscript.

\section{Funding}

Open Access funding enabled and organized by Projekt DEAL.

\section{Availability of data and materials}

The datasets used and/or analyzed during the current study are available from the corresponding author on reasonable request.

\section{Declarations}

Ethics approval and consent to participate

Not applicable.

Consent for publication

Not applicable.

\section{Competing interests}

The authors declare that they have no competing interests.

Received: 10 April 2020 Accepted: 26 April 2021

Published online: 19 May 2021

References

1. Haas R, Panzer C, Resch G, Ragwitz M, Reece G, Held A (2011) A historical review of promotion strategies for electricity from renewable energy sources in EU countries. Renew Sust Energ Rev 15(2):1003-1034. https://doi.org/10. 1016/j.rser.2010.11.015

2. IEA (International Energy Agency) (2015) IEA Statistics. Key Renewable Trends. Excerpt from: Renewables Information. http://www.iea.org/publications/ freepublications/publication/RENTEXT 2015_PARTIIExcerpt.pdf. Accessed 25 Jan 2016

3. IEA (International Energy Agency) (2016) World Energy Outlook. http://www. iea.org/publications/freepublications/publication/WEO2016_ExecutiveS ummary_Germanversion.pdf. Accessed 17 Apr 2017 
4. Eurostat (2016) Greenhouse gas emission statistics. http://ec.europa.eu/euros tat/statistics-explained/index.php/Greenhouse_gas_emission_statistics. Accessed 16 Feb 2017

5. Oberthür S, Kelly CR (2008) EU Leadership in international climate policy: achievements and challenges. Int Spect 43(3):35-50. https://doi.org/10.1080/ 03932720802280594

6. Parker CF, Karlsson C (2010) Climate change and the European Union's leadership moment: an inconvenient truth? J Common Mark Stud 48(4):923-943. https://doi.org/10.1111/j.1468-5965.2010.02080.x

7. Eurostat (2017) Renewable energy in the EU. Share of renewables in energy consumption in the EU still on the rise to almost 17\% in 2015. http://ec. europa.eu/eurostat/documents/2995521/7905983/8-14032017-BP-EN.pdf/ af8b4671-fb2a-477b-b7cf-d9a28cb8beea. Accessed 03 Apr 2017

8. BMUB (Federal Ministry for the Environment, Nature Conservation, Building and Nuclear Safety) (2014) The German Government's Climate Action Programme 2020. http://www.bmub.bund.de/fileadmin/Daten_BMU/Pools/ Broschueren/aktionsprogramm_klimaschutz_2020_broschuere_en_bf.pdf. Accessed 15 Jul 2016

9. UBA (Federal Environment Agency) (2016) National Inventory Report, Germany - 2016. https://www.umweltbundesamt.de/sites/default/files/ medien/378/publikationen/climate_change_24_2016_submission_under_ the_united_nations_framework_nir_2016.pdf. Accessed 18 Jul 2016

10. EEG (Renewable Energy Sources Act - RES Act) (2000) http://www.bmub. bund.de/fileadmin/bmu-import/files/pdfs/allgemein/application/pdf/resact.pdf. Accessed 20 Apr 2015

11. BMWi (Federal Ministry for Economic Affairs and Energy) (2015) The Energy of the Future. http://www.bmwi.de/English/Redaktion/Pdf/vierter-monitoringbericht-energie-der-zukunft-kurzfassung,property=pdf,bereich=bmwi2 012,sprache=en,rwb=true.pdf. Accessed 29 Jan 2016

12. EEG (Renewable Energy Sources Act - RES Act) (2014) http://www.bmwi.de/ English/Redaktion/Pdf/renewable-energy-sources-act-eeg-2014,property= pdf,bereich=bmwi2012,sprache=en,rwb=true.pdf. Accessed 20 Apr 2015

13. Aravena C, Hutchinson WG, Longo A (2012) Environmental pricing of externalities from different sources of electricity generation in Chile. Energ Econ 34(4):1214-1225. https://doi.org/10.1016/j.eneco.2011.11.004

14. Gerpott TJ, Mahmudova I (2010) Determinants of green electricity adoption among residential customers in Germany. Int J Consum Stud 34(4):464-473. https://doi.org/10.1111/j.1470-6431.2010.00896.x

15. Hansla A (2011) Value orientation and framing as determinants of stated willingness to pay for eco-labeled electricity. Energ Effic 4(2):185-192. https:// doi.org/10.1007/s12053-010-9096-0

16. Kaenzig J, Heinzle SL, Wüstenhagen R (2013) Whatever the customer wants, the customer gets? Exploring the gap between consumer preference and default electricity products in Germany. Energ Policy 53:311-322. https://doi. org/10.1016/j.enpol.2012.10.061

17. Litvine D, Wüstenhagen R (2011) Helping "light green" consumers walk the talk: results of a behavioral intervention survey in the Swiss electricity market. Ecol Econ 70(3):462-474. https://doi.org/10.1016/j.ecolecon.2010.10.005

18. Longo A, Markandya A, Petrucci M (2008) The internalization of externalities in the production of electricity: willingness to pay for the attributes of a policy for renewable energy. Ecol Econ 67(1):140-152. https://doi.org/10. 1016/j.ecolecon.2007.12.006

19. Oliver H, Volschenk J, Smit E (2011) Residential consumers in the Cape Peninsula's willingness to pay for premium priced green electricity. Energ Policy 39(2):544-550. https://doi.org/10.1016/j.enpol.2010.10.012

20. Ma C, Rogers AA, Kragt ME, Zhang F, Polyakov M, Gibson F, Chalak M, Pandit R, Tapsuwan S (2015) Consumers' willingness to pay for renewable Energy: a meta-regression analysis. Resour Energ Econ 42:93-109. https://doi.org/10. 1016/j.reseneeco.2015.07.003

21. Sundt S, Rehdanz K (2015) Consumer's willingness to pay for green electricity: a meta-analysis of the literature. Energ Econ 51:1-8. https://doi.org/10.1016/j. eneco.2015.06.005

22. Andor MA, Frondel M, Vance C (2017) Germany's Energiewende: a tale of increasing costs and decreasing willingness-to-pay. Energy J 38(KAPSARC Special Issue)

23. Batley SL, Colbourne D, Fleming PD, Urwin P (2001) Citizen versus consumer: challenges in the UK green power market. Energ Policy 29(6):479-487. https://doi.org/10.1016/S0301-4215(00)00142-7

24. Salmela S, Varho V (2006) Consumers in the green electricity market in Finland. Energ Policy 34(18):3669-3683. https://doi.org/10.1016/j.enpol.2005. 08.008
25. Gamble A, Juliusson EA, Gärling T (2009) Consumer attitudes towards switching supplier in three deregulated markets. J Socio-Econ 38(5):814-819. https://doi.org/10.1016/j.socec.2009.05.002

26. Sunderer G (2006) Was hält Verbraucher vom Wechsel zu Ökostrom ab? Universität Trier, Schriftenreihe des Zentrums für europäische Studien

27. Yang Y (2014) Understanding household switching behavior in the retail electricity market. Energ Policy 69:406-414. https://doi.org/10.1016/j.enpol. 2014.03.009

28. Borchers AM, Duke JM, Parsons GR (2007) Does willingness to pay differ by source? Energ Policy 35(6):3327-3334. https://doi.org/10.1016/j.enpol.2006. 12.009

29. Yang Y, Solgaard HS, Haider W (2016) Wind, hydro or mixed renewable energy source: preference for electricity products when the share of renewable energy increases. Energ Policy 97:521-531. https://doi.org/10.1016/j.enpol. 2016.07.030

30. Herrmann A (2013) Biogas production from maize: current state, challenges and prospects. 2. Agron Environ Aspects. Bioenerg Res 6(1):372-387

31. Kintisch E (2010) Out of site. Science 329(5993):788-798. https://doi.org/10. 1126/science.329.5993.788

32. Wüstenhagen $R$, Wolsink M, Bürer MJ (2007) Social acceptance of renewable energy innovation: an introduction to the concept. Energ Policy 35(5):26832691. https://doi.org/10.1016/j.enpol.2006.12.001

33. Zschache U, von Cramon-Taubadel S, Theuvsen L (2010) Öffentliche Deutungen im Bioenergiediskurs: eine qualitative Medienanalyse. Ber Ldw 88(3):502-512

34. Burkhalter A, Kaenzig J, Wüstenhagen R (2009) Kundenpräferenzen für leistungsrelevante Attribute von Stromprodukten. ZfE, Zeitschrift für Energiewirtschaft 2:161-172

35. Groesche P, Schroeder C (2011) Eliciting public support for greening the electricity mix using random parameter techniques. Energ Econ 33(2):363-370. https://doi.org/10.1016/j.eneco.2010.10.002

36. PWC (Pricewaterhouse Coopers), 2015. Bevölkerungsbefragung Stromanbieter. https://www.pwc.de/de/energiewirtschaft/assets/pwc-umfrage-energ ie.pdf. Accessed 23 Feb 2017

37. List JA, Sinha P, Taylor MH (2006) Using choice experiments to value nonmarket goods and services: evidence from field experiments. Adv Econ Anal Policy. https://doi.org/10.2202/1538-0637.1132

38. Fiebig DG, Keane MP, Louviere JJ, Wasi N (2010) The generalized multinomial logit model: accounting for scale and coefficient heterogeneity. Market Sci 29(3):393-421. https://doi.org/10.1287/mksc.1090.0508

39. Greene WH, Hensher DA (2010) Does scale heterogeneity across individuals matter? An empirical assessment of alternative logit models. Transp 37(3):413-428. https://doi.org/10.1007/s11116-010-9259-z

40. Balogh P, Békési D, Gorton M, Popp J, Lengyel P (2016) Consumer willingness to pay for traditional food products. Food Pol 61:176-184. https://doi.org/10. 1016/j.foodpol.2016.03.005

41. Balcombe K, Chalak A, Fraser I (2009) Model selection for the mixed logit with Bayesian estimation. J Environ Econ Manag 57(2):226-237. https://doi.org/10. 1016/j.jeem.2008.06.001

42. Balcombe K, Fraser I, Falco SD (2010) Traffic lights and food choice: a choice experiment examining the relationship between nutritional food labels and price. Food Pol 35(3):211-220. https://doi.org/10.1016/j.foodpol.2009.12.005

43. Cicia G, Cembale L, Del Giudice T, Palladino A (2012) Fossil energy versus nuclear, wind, solar, and agricultural biomass: insights from an Italian national survey. Energ Policy 42:59-66. https://doi.org/10.1016/j.enpol.2011.11.030

44. Ek K (2005) Public and private attitudes towards "green" electricity: the case of Swedish wind power. Energ Policy 33(13):1677-1689. https://doi.org/10. 1016/j.enpol.2004.02.005

45. Gracia A, Barreiro-Hurlé J, Peréz y Peréz L, (2012) Can renewable energy be financed with higher electricity prices? Evidence from a Spanish region. Energ Policy 50:784-794. https://doi.org/10.1016/j.enpol.2012.08.028

46. Kosenius AK, Ollikainen M (2013) Valuation of environmental and societal trade-offs of renewable energy sources. Energ Policy 62:1148-1156. https:// doi.org/10.1016/j.enpol.2013.07.020

47. Heidjann J (2017a) Regional unterschiedliche Strompreise in Deutschland. https://www.stromauskunft.de/strompreise/stromvergleich-fuer-deuts chland/. Accessed 17 Apr 2017

48. Strom-Report (2017a) Wo ist Ökostrom am günstigsten? https://1-stromvergl eich.com/strom-report/oekostrom/\#oekostrom-preisvergleich. Accessed 17 Feb 2017 
49. Liebe $U$, Bartczak A, Meyerhoff J (2017) A turbine is not only a turbine: the role of social context and fairness characteristics for the local acceptance of wind power. Energ Policy 107:300-308. https://doi.org/10.1016/j.enpol.2017. 04.043

50. Meyerhoff J (2013) Do turbines in the vicinity of respondents' residences influence choices among programms for future wind power generation? J Choice Model 7:58-71. https://doi.org/10.1016/j.jocm.2013.04.010

51. Klaassen G, Miketa A, Larsen K, Sundqvist T (2005) The impact of R\&D on innovation for wind energy in Denmark, Germany and the United Kingdom. Ecol Econ 54(2-3):227-240. https://doi.org/10.1016/j.ecolecon.2005.01.008

52. Kramer R (2015) Gesetzliche Rahmenbedingungen und ihre Auswirkungen auf die Vermarktung von Erneuerbaren Energien in Deutschland. In: Herbes C, Friege C (eds) Marketing Erneuerbarer Energien. Springer Fachmedien, Wiesbaden, pp 61-80

53. BDEW (Federal Association of the German Energy and Water Industries) (2017) BDEW-Strompreisanalyse February 2017. https://www.bdew.de/inter net.nsf/id/BDCFF33EA21E8D9BC12580C8004CC2B8/\$file/170213_AUSZUG_ BDEW_Strompreisanalyse Februar2017.pdf. Accessed 14 Mar 2017

54. AEE (Renewable Energies Agency) (2015) Renews Kompakt. https://www. unendlich-viel-energie.de/media/file/416.AEE_RenewsKompakt_Akzeptanzu mfrage2015.pdf. Accessed 26 Jan 2017

55. Dickenberger D, Gniech G, Grabitz HJ (1993) Die Theorie der psychologischen Reaktanz. In Frey D, Irle M (Eds.) Theorien der Sozialpsychologie, Band 1: Kognitive Theorien: 243-276. Bern, Huber

56. Clark CF, Kotchen MJ, Moore MR (2003) Internal and external influences on pro-environmental behavior: participation in a green electricity program. J Environ Psychol 23(3):237-246. https://doi.org/10.1016/S0272-4944(02) 00105-6

57. Wiser $\mathrm{RH}$ (2007) Using contingent valuation to explore willingness to pay for renewable energy: a comparison of collective and voluntary payment vehicles. Ecol Econ 62(3):419-432. https://doi.org/10.1016/j.ecolecon.2006.07. 003

58. Tabi A, Hille SL, Wüstenhagen R (2014) What makes people seal the green power deal? - Customer segmentation based on choice experiment in Germany. Ecol Econ 107:206-215. https://doi.org/10.1016/j.ecolecon.2014.09. 004

59. MacPherson R, Lange I (2013) Determinants of green electricity tariff uptake in the UK. Energ Policy 62:920-933. https://doi.org/10.1016/j.enpol.2013.07. 089

60. Kotchen MJ, Moore MR (2007) Private provision of environmental public goods: household participation in green-electricity programs. J Environ Econ Manage 53(1):1-16. https://doi.org/10.1016/j.jeem.2006.06.003

61. Friege C, Herbes C (2015) Konzeptionelle Überlegungen zur Vermarktung von Erneuerbaren Energien. In: Herbes C, Friege C (eds) Marketing Erneuerbarer Energien. Springer Fachmedien, Wiesbaden, pp 3-28

62. Federal Network Agency (2016) Monitoringbericht 2016. https://www.bunde snetzagentur.de/SharedDocs/Downloads/DE/Sachgebiete/Energie/Unter nehmen_Institutionen/DatenaustauschUndMonitoring/Monitoring/Monit oringbericht2016.pdf? _blob=publicationFile\&v=2. Accessed 29 Dec 2016

63. Louviere JJ, Hensher DA, Swait JD (2000) Stated choice methods: analysis and applications, 1st edn. University Press, Cambridge

64. Train KE (2009) Discrete choice methods with simulation, 2nd edn. University Press, Cambridge

65. Hanley N, Ryan M, Wright R (2003) Estimating the monetary value of health care: lessons from environmental economics. Health Econ 12(1):3-16. https:// doi.org/10.1002/hec.763

66. Heidjann J (2017b) Stromtarife. https://www.stromauskunft.de/strompreise/ stromtarife. Accessed 30 Jan 2017

67. Louviere JJ, Islam T, Wasi N, Street D, Burgess L (2008) Designing discrete choice experiments: do optimal designs come at a price? J Consum Res 35:360-375. https://doi.org/10.1086/586913

68. Rose JM, Bliemer MCJ (2009) Constructing efficient stated choice experimental design. Transp Rev 29(5):587-617. https://doi.org/10.1080/0144164090 2827623
69. Bliemer MC, Rose JM, Hess S (2008) Approximation of Bayesian efficiency in experimental choice designs. J Choice Model 1(1):98-127. https://doi.org/10. 1016/S1755-5345(13)70024-1

70. Ferrini S, Scarpa R (2007) Designs with a priori information for nonmarket valuation with choice experiments: a Monte Carlo study. J Environ Econ Manage 53(3):342-363. https://doi.org/10.1016/j.jeem.2006.10.007

71. Sandor Z, Wedel M (2005) Heterogeneous conjoint choice designs. J Market Res 42(2):210-218. https://doi.org/10.1509/jmkr.42.2.210.62285

72. Scarpa R, Rose JM (2008) Design efficiency for non-market valuation with choice modelling: how to measure it, what to report and why. Australian J Agric Resour Econ 52(3):253-282. https://doi.org/10.1111/j.1467-8489.2007. 00436.x

73. Hensher DA, Greene WH (2011) Valuation of travel time savings in WTP and preference space in the presence of taste and scale heterogeneity. J Transp Econ Pol 45(3):505-525

74. Li X, Clark CD, Jensen KL, Yen ST (2014) Will consumers follow climate leaders? The effect of manufacturer participation in a voluntary environmental program on consumer preferences. Environ Econ Pol Stud 16(1):69-87

75. Coffie RO, Burton MP, Gibson FL, Hailu A (2016) Choice of rice production practices in Ghana: a comparison of willingness to pay and preference space estimates. J Agric Econ 67(3):799-819. https://doi.org/10.1111/1477-9552. 12180

76. Sauthoff S, Musshoff O, Danne M, Anastassiadis F (2016) Sugar beet as a biogas substrate? A discrete choice experiment for the design of substrate supply contracts for German farmers. Biomass Bioenergy 90:163-172. https:// doi.org/10.1016/j.biombioe.2016.04.005

77. BiB (German Federal Institute for Population Research) (2017) Mean age of the population in Germany. ww.bib-demografie.de/EN/Facts_Figures/Pop_ Balance/Figures/a_02_15_durchschnittsalter_d_ab1871.html. Accessed 11 May 2017

78. Destatis (German Federal Statistical Office) (2016) Statistisches Jahrbuch 2016. Wiesbaden

79. Federal Returning Officer (2017) Bundestag election 2017. https://www. bundeswahlleiter.de/en/bundestagswahlen/2017/ergebnisse/bund-99.html. Accessed 29 Apr 2018

80. GuY, Hole AR, Knox S (2013) Fitting the generalized multinomial logit model in Stata. Stata J 13:382-397

81. Hensher DA, Rose JM, Greene WH (2005) Applied choice analysis: a primer. University Press, Cambridge

82. Strom-Report (2018) Netzentgelte. https://1-stromvergleich.com/stromreport/netzentgelte/. Accessed 25 Apr 2018

83. Strom-Report (2017b) Zusammensetzung der EEG-Umlage und Entwicklung der Einflussfaktoren. https://1-stromvergleich.com/strom-report/eeg-umlag e/\#eeg-umlage-2017. Accessed 7 Feb 2017

84. UBA (Federal Environment Agency), (2010) Energy target 2050: 100\% renewable electricity supply. Dessau-Roßlau, Germany

85. Schmidt J, Bijmolt TH (2020) Accurately measuring willingness to pay for consumer goods: a meta-analysis of the hypothetical bias. J Acad Market Sci 48(3):499-518. https://doi.org/10.1007/s11747-019-00666-6

86. Lagarde M, Blaauw D (2009) A review of the application and contribution of discrete choice experiments to inform human resources policy interventions. Hum Resour Health 7(1):1-10. https://doi.org/10.1186/1478-4491-7-62

87. Byrnes B, Jones C, Goodman S (1999) Contingent valuation and real economic commitment: evidence from electric utility green pricing programmes. J Environ Plan Manage 42(2):149-166. https://doi.org/10.1080/ 09640569911190

\section{Publisher's Note}

Springer Nature remains neutral with regard to jurisdictional claims in published maps and institutional affiliations. 